\title{
Article \\ Unconventional Gold-Catalyzed One-Pot/Multicomponent Synthesis of Propargylamines Starting from Benzyl Alcohols
}

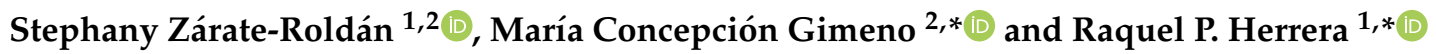 \\ 1 Laboratorio de Organocatálisis Asimétrica, Departamento de Química Orgánica, Instituto de Síntesis Química \\ y Catálisis Homogénea (ISQCH), CSIC-Universidad de Zaragoza, C/ Pedro Cerbuna 12, \\ 50009 Zaragoza, Spain; szarate.roldan@gmail.com \\ 2 Departamento de Química Inorgánica, Instituto de Síntesis Química y Catálisis Homogénea (ISQCH), \\ CSIC-Universidad de Zaragoza, C/ Pedro Cerbuna 12, 50009 Zaragoza, Spain \\ * Correspondence: gimeno@unizar.es (M.C.G.); raquelph@unizar.es (R.P.H.); Tel.: +34-976-762-291 (M.C.G.); \\ +34-976-761-190 (R.P.H.)
}

check for

updates

Citation: Zárate-Roldán, S.; Gimeno, M.C.; Herrera, R.P. Unconventional Gold-Catalyzed One-Pot/

Multicomponent Synthesis of Propargylamines Starting from Benzyl Alcohols. Catalysts 2021, 11, 513. https://doi.org/10.3390/ catal11040513

Academic Editors: Alfonso Iadonisi and Serena Traboni

Received: 30 March 2021

Accepted: 15 April 2021

Published: 19 April 2021

Publisher's Note: MDPI stays neutral with regard to jurisdictional claims in published maps and institutional affiliations.

Copyright: (c) 2021 by the authors. Licensee MDPI, Basel, Switzerland. This article is an open access article distributed under the terms and conditions of the Creative Commons Attribution (CC BY) license (https:/ / creativecommons.org/licenses/by/ $4.0 /)$.

\begin{abstract}
A formal homogeneous gold-catalyzed $\mathrm{A}^{3}$-coupling, starting from benzyl alcohols, is reported for the straightforward synthesis of propargylamines. This is the first process where these highly valuable compounds have been synthesized, starting from the corresponding alcohols in a one-pot oxidation procedure using $\mathrm{MnO}_{2}$, followed by a $\mathrm{HAuCl}_{4} \cdot 3 \mathrm{H}_{2} \mathrm{O}$ catalyzed multicomponent reaction. The final products are obtained with very good yields in short reaction times, which is of fundamental interest for the synthesis of pharmaceuticals. The usefulness and efficiency of our methodology is successfully compared against the same reaction starting from aldehydes.
\end{abstract}

Keywords: benzyl alcohols; gold; multicomponent; one-pot; propargylamine

\section{Introduction}

Nowadays, organic synthesis is more focused on both efficiency and environmental sustainability due to increasing concern about the prevention of pollution and waste minimization, as the main aims of Green Chemistry. Among the number of developed processes, one-pot procedures [1-4] and multicomponent reactions (MCR) [5-7] are at the forefront of these green and eco-friendly approaches. In the last decade, these protocols have been the center of great attention, especially in the pharmaceutical industry, because of the easy formation of large libraries of organic compounds with biological activities [8-11]. These processes are interesting due to the necessity of a single reaction vessel, while minimizing chemical waste, saving time, solvents and energy, and simplifying practical aspects.

The oxidation of primary alcohols is one of the main reactions in organic synthesis to directly obtain aldehydes [12]. Many organic reactions start from aldehydes and some of them lead to products of biological interest. However, the direct use of different aldehydes could be considered sometimes somewhat toxic, more expensive and overall, more difficult to handle and work with. Moreover, we realized that when using aldehydes, the catalytic traces of acid contained in these reagents could negatively affect the results of the processes (yield and/or enantioselectivity), which might inhibit the catalyst performance [13]. In this field, we pioneered one of the scarce approaches where the in situ-generated aldehyde was further used in an ulterior organocatalytic reaction [14]. It is remarkable that although there exist different protocols for the oxidation of alcohols, the subsequent use of the carbonyl group generated in the oxidation step in a cascade catalytic process is rarer [15-19]. We envisaged that the catalytic reactions starting from the corresponding alcohol would be more convenient than those starting from aldehydes, mainly due to the higher availability and easy handling of the former. Additionally, it is interesting for the final outcome of the reaction, since sometimes the high reactivity of the aldehyde could interfere in other aspects of the multi-step synthesis. 
Among the plethora of reactions in the literature that start from an aldehyde, the three-component $\mathrm{A}^{3}$-coupling for the synthesis of propargylamines and catalyzed by a transition metal between an aldehyde, an alkyne and an amine is of great relevance [20-26]. This approach is the focus of continued interest and has been established as a general route for the construction of nitrogen-containing compounds, giving rise to appealing scaffolds with interesting biological properties (Figure 1). It is remarkable the presence of propargylamine cores in compounds such as Pargyline I, a biological active compound involved in the inhibition of MAO-B (Monoamine Oxidase B) and used against neurodegenerative diseases such as Parkinson's or Alzheimer's [27,28]. DPC 961 II is also an interesting active compound, used as a second-generation NNRTI (non-nucleoside reverse transcriptase inhibitors) drug with enhanced activity compared to Efavirenz, the treatment of human immunodeficiency virus (HIV) infection [29-31]. Moreover, 1,2,3,4-tetrahydroisoquinoline alkaloids III and IV are interesting natural products also obtained after a propargylamine intermediate [25].<smiles>C#CCN(C)Cc1ccccc1</smiles>

I

Pargyline<smiles>C[C@]1(C#CC2CC2)NC(=O)Nc2ccc(Cl)cc21</smiles>

II second-generation NNRTI<smiles>COc1cc2c(cc1OC)[C@@H]1CCCN1CC2</smiles>

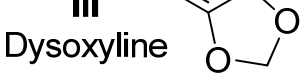

Figure 1. Biologically active propargylamines and natural amines derived from propargylamines.

On the other hand, in the last two decades, the chemistry of gold as a catalyst has emerged as a powerful tool to promote numerous organic transformations [32-43]. It is worth noting that the use of gold catalysts, in homogeneous catalysis, for the preparation of propargylamines has been reported so far [44-55]. There are also pivotal examples of the use of gold nanoparticles in heterogeneous catalysis [56-67]. Due to the importance of the propargylamine structural cores, the development of new more straightforward and sustainable methodologies for building these skeletons is still of great interest. During the preparation of this work, Hwang's group reported the pioneering preparation of propargylamines by a visible-light-mediated copper-catalyzed photoredox hydrogen-atom transfer process [68]. The process was developed using $\mathrm{CuCl}(5 \mathrm{~mol} \%)$ and benzoquinone (1.2 equiv.) at room temperature with blue LEDS (light-emitting diodes) and after, up to $24 \mathrm{~h}$. Later on, Shahverdizadeh's group reported the use of silica-encapsulated gold nanoparticles as a nano-reactor for aerobic oxidation of benzyl alcohols and heterogeneous tandem preparation of final propargylamines [69]. It is also remarkable the work pioneered by Dabiri's group in 2014 in a similar reaction, using gold nanoparticles supported on graphene oxide with ionic liquid framework (Au@GO-IL) using high temperature $\left(100^{\circ} \mathrm{C}\right)$ and water as a solvent [70]. However, and to the best of our knowledge, the method reported here is the simplest one to synthesize propargylamines starting from an alcohol and with commercially available oxidant and catalyst. Therefore, this work could represent a crucial precedent of this undeveloped approach (Scheme 1). 


\section{Previous works}

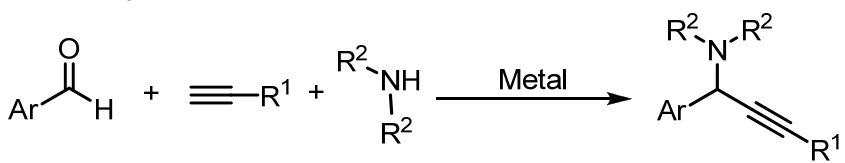

\section{This work}

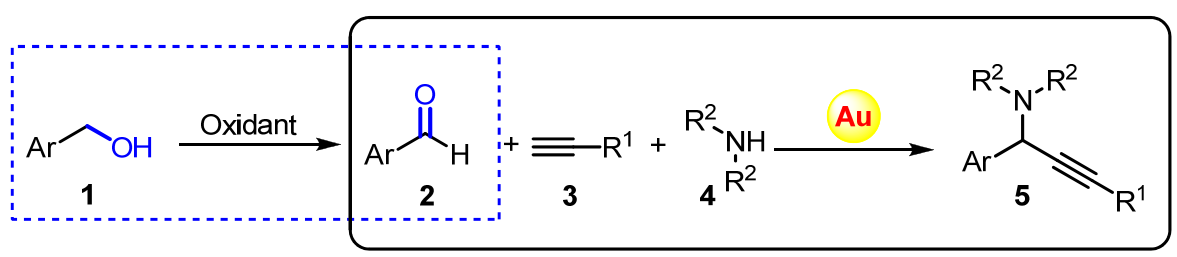

Scheme 1. Hypothesis of work for a $\mathrm{A}^{3}$-coupling reaction starting from benzyl alcohols.

\section{Results and Discussion}

Focused on our previous work [14] and analyzing many different oxidants reported in the literature, we chose activated manganese dioxide, $\mathrm{MnO}_{2}$, as the mildest oxidant and as the most selective and efficient one to straightforward obtain the corresponding aldehydes [71].

We started with a selection of representative and accessible metallic salts (Table 1 , entries 1-5). Interestingly, all catalysts assayed were able to promote the catalytic reaction, adding all the reagents in a one-pot/multicomponent procedure, without the necessity of isolating the in situ-generated aldehyde $\mathbf{2 a}$. Remarkably, the gold derivative afforded a total conversion of the process after $2 \mathrm{~h}$ of reaction, with a $5 \mathrm{~mol} \%$ of catalyst and with better results in comparison with the other tested species (Table 1, entry 1).

Table 1. Screening of the reaction condition using a model reaction ${ }^{(a)}$.

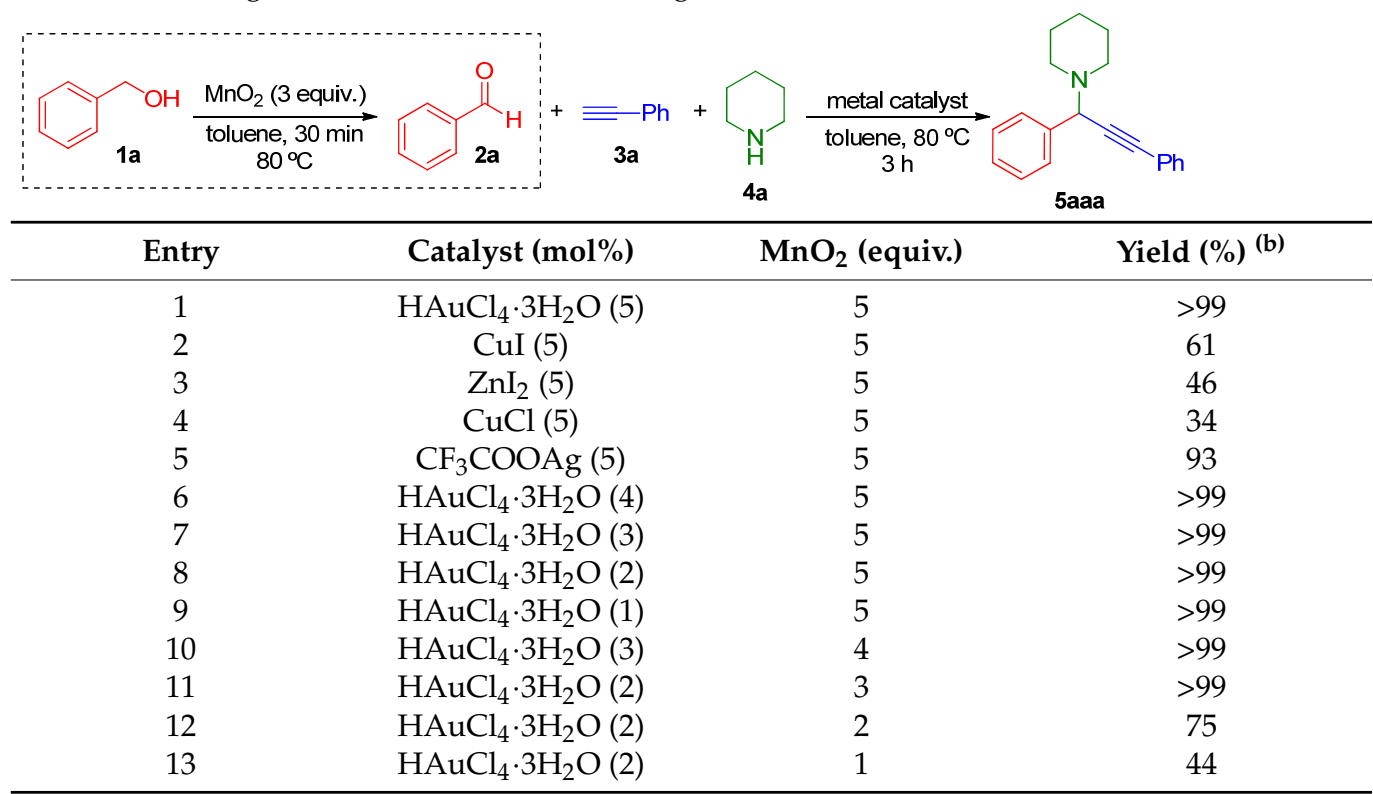

(a) Otherwise indicated: benzyl alcohol 1a $(0.5 \mathrm{mmol})$ was solved in $0.5 \mathrm{~mL}$ of toluene and $\mathrm{MnO}_{2}(1-5$ equiv. was further added. Then, the oxidation step was performed at $80^{\circ} \mathrm{C}$ for $30 \mathrm{~min}$. Subsequently, $\mathrm{HAuCl}_{4} \cdot 3 \mathrm{H}_{2} \mathrm{O}$ $(1-5 \mathrm{~mol} \%)$, piperidine $4 \mathbf{a}(0.55 \mathrm{mmol})$ and phenylacetylene $3 \mathbf{a}(0.6 \mathrm{mmol})$ were added to the same vessel at $80^{\circ} \mathrm{C}$ for $2.5 \mathrm{~h}$. (b) Yields calculated by ${ }^{1} \mathrm{H}-\mathrm{NMR}$ vs the aldehyde as the limiting reagent.

In a second step, we studied the variation of catalyst loading, using $\mathrm{HAuCl}_{4} \cdot 3 \mathrm{H}_{2} \mathrm{O}$ from 5 to $1 \mathrm{~mol} \%$ (Table 1, entries 1,6-9). In all cases, the final products were obtained with excellent results after a short reaction time $(3 \mathrm{~h})$. At this point, we decided to continue with $2 \mathrm{~mol} \%$ of gold in the subsequent study. Finally, we explored in more detail the oxidation of benzylic alcohol 1a to give the corresponding benzaldehyde $2 \mathbf{a}$ with different amounts of 
$\mathrm{MnO}_{2}$ (Table 1, entries 10-13). To our delight, the best conditions were obtained using only 3 equiv. of $\mathrm{MnO}_{2}$ in toluene at $80^{\circ} \mathrm{C}$ and after only $30 \mathrm{~min}$ of reaction for the oxidation step. It is worth noting that the normal conditions using $\mathrm{MnO}_{2}$ in other oxidation processes of benzyl alcohols required longer reaction times ( 1 to $70 \mathrm{~h}$ or longer) and greater amounts of equivalents of $\mathrm{MnO}_{2}$ (between 5 and 20) [12]. Therefore, we have successfully achieved to smooth the reaction conditions for this step, considerably decreasing the necessary amount of oxidation source.

With the best reaction conditions in hand, we explored the viability of our working hypothesis studying the scope of the reaction using different alcohols 1 , alkynes 3 and amines 4 (Table 2).

Table 2. Scope of the one-pot/multicomponent preparation of propargylamines $5^{\text {(a) }}$.

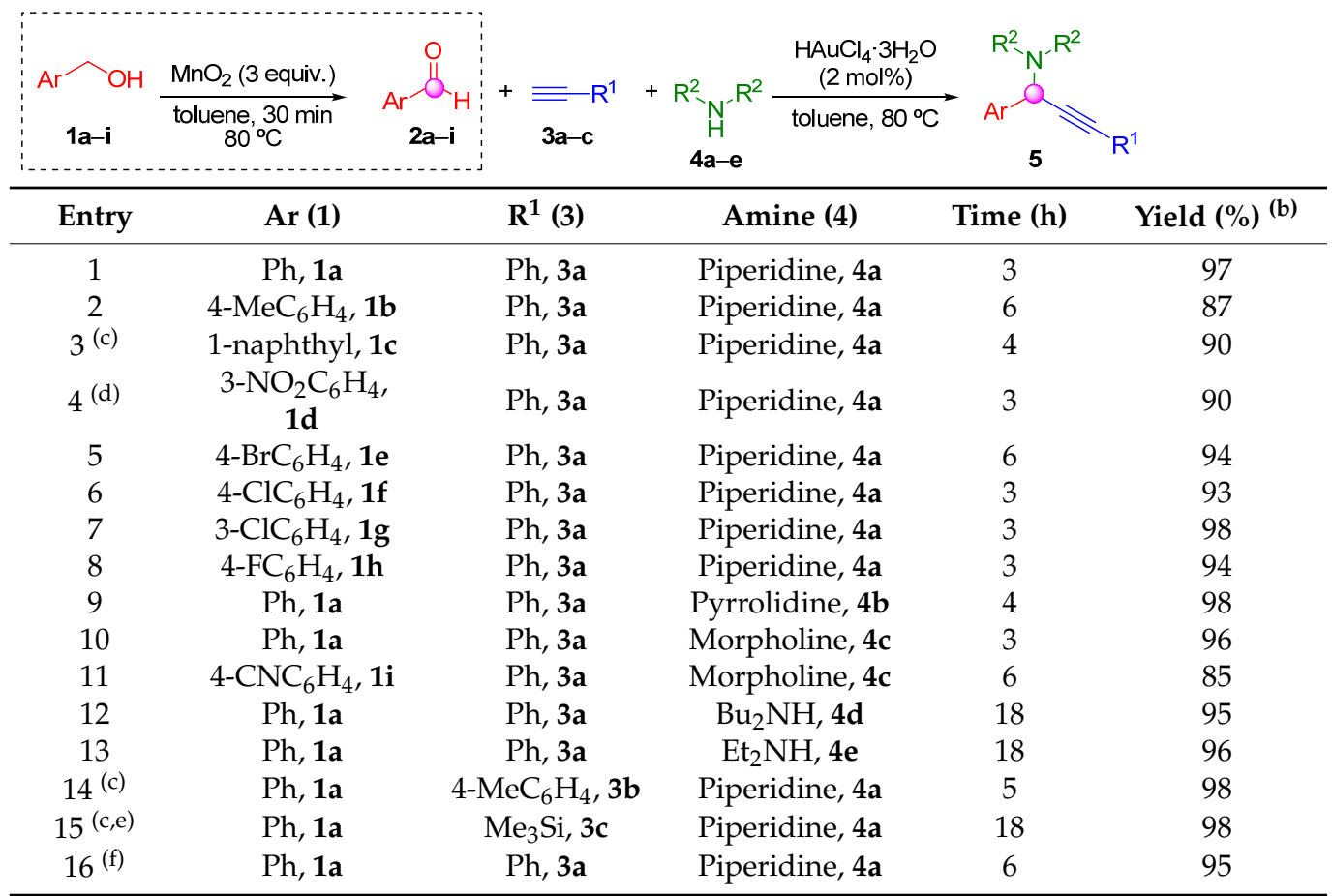

(a) Alcohol 1a-i $(0.5 \mathrm{mmol})$ was solved in $0.5 \mathrm{~mL}$ of toluene and $\mathrm{MnO}_{2}(1.5 \mathrm{mmol}, 144.9 \mathrm{mg})$ was further added Then, the oxidation step was performed at $80{ }^{\circ} \mathrm{C}$ for $30 \mathrm{~min}$. Subsequently, $\mathrm{HAuCl}_{4} \cdot 3 \mathrm{H}_{2} \mathrm{O}(2 \mathrm{~mol} \%)$, amine $4 a-e$ $(0.55 \mathrm{mmol})$ and alkyne $3 \mathrm{a}-\mathrm{c}(0.6 \mathrm{mmol})$ were added to the same vessel at $80^{\circ} \mathrm{C}$ for the necessary reaction time. (b) Isolated yield after column chromatography (neutral alumina, $n$-hexane:diethylether $95: 5)$. (c) Using $3 \mathrm{~mol} \%$ of $\mathrm{HAuCl}_{4} \cdot 3 \mathrm{H}_{2} \mathrm{O}$. ${ }^{(\mathrm{d})}$ The oxidation step takes $1 \mathrm{~h}$ to be completed. ${ }^{(\mathrm{e})}$ Using 2 equiv. of ethynyltrimethylsilane $3 \mathrm{c}$.

(f) For a preparative scale, $4 \mathrm{mmol}$ of $\mathbf{1 a}$ is used.

In general, the final propargylamines 5 were obtained with very good yields (up to 98\%) after column chromatography. The results do not suggest a clear correlation between the reactivity of the process with the electronic properties of the starting alcohols. However, it can be inferred that there is a slightly reduced reactivity when the in situ-generated aldehydes bear electron donor substituents, as would be expected (see $\mathbf{1 b}$ and $\mathbf{1 c}$, entries 2 and 3). Interestingly, the reaction worked well for different cyclic and non-cyclic secondary amines (4a-e) and various alkynes (3a-c), obtaining in all cases almost quantitative yields $(>95 \%)$. It is remarkable that this catalytic system allows for scaling up the reaction, since the same excellent result, in terms of reactivity, was obtained when the reaction was scaled up 8 times (Table 2, entry 16).

The structures of the final products of this protocol have been also confirmed by the single-crystal analysis of compounds 5aaa and 5caa (Figure 2). 


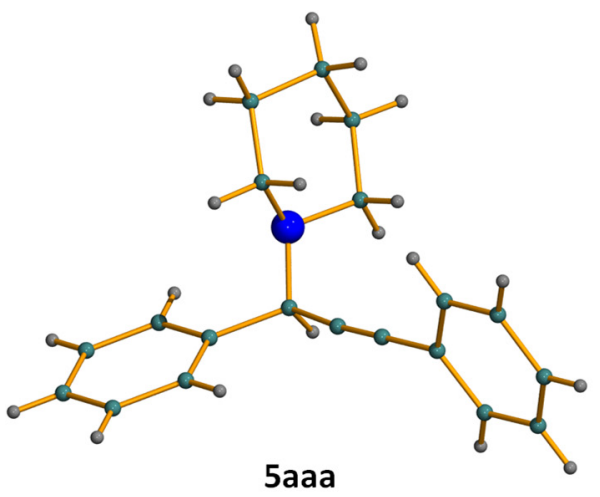

5 aaa

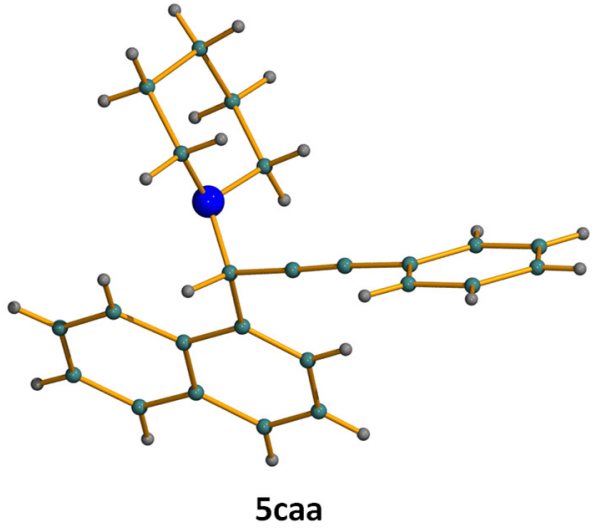

5 caa

Figure 2. X-ray crystal structures of 5aaa and 5caa.

In order to prove that our methodology is efficient and that it could be the best option, we have compared the results of the process starting from the alcohol $\mathbf{1 d}-\mathbf{g}, \mathbf{i}$ or from the corresponding commercially available aldehyde (without purification) $\mathbf{2} \mathbf{d}-\mathbf{g}, \mathbf{i}$ (Table 3).

Table 3. Comparative one-pot/multicomponent process starting from the alcohol $\mathbf{1 d}-\mathbf{g}, \mathbf{i}$ and the aldehyde $\mathbf{2 d}-\mathbf{g}, \mathbf{i}^{(\mathrm{a}, \mathrm{b})}$.

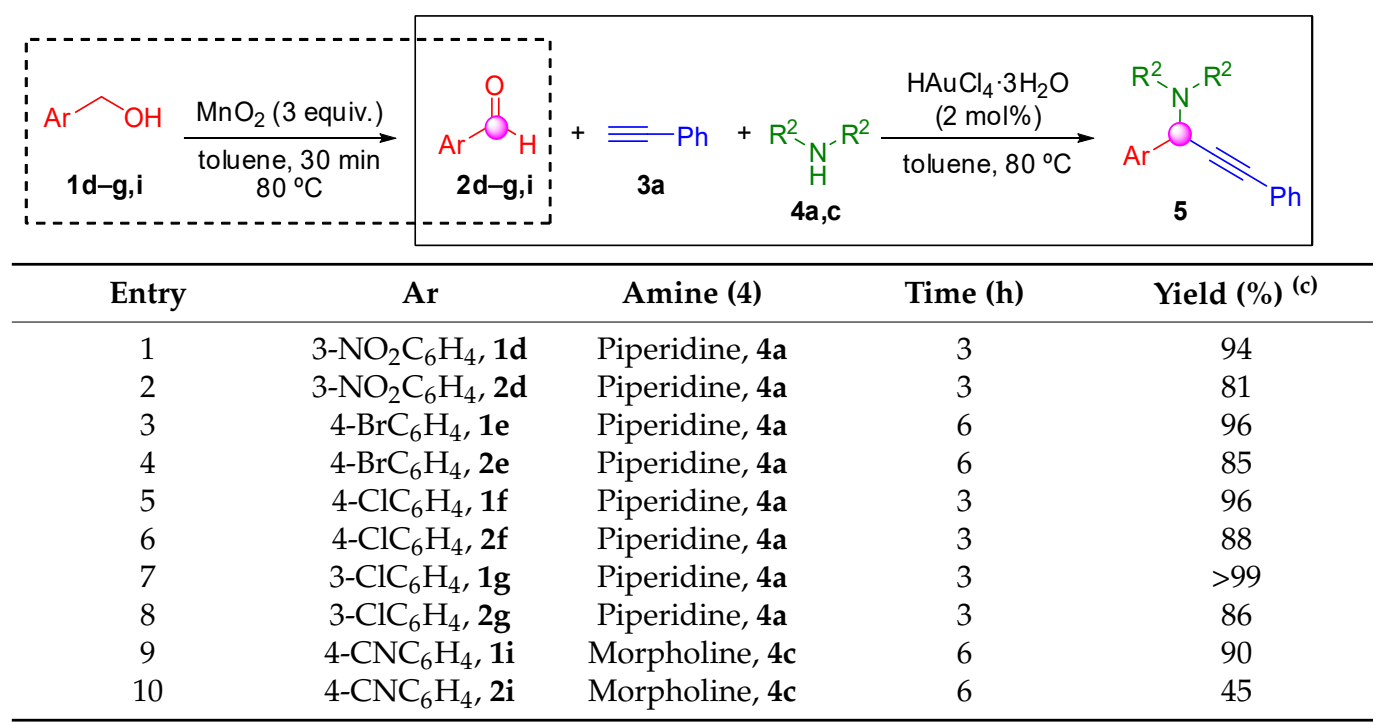

(a) Alcohol 1d-g,i $(0.5 \mathrm{mmol})$ was solved in $0.5 \mathrm{~mL}$ of toluene and $\mathrm{MnO}_{2}(1.5 \mathrm{mmol}, 144.9 \mathrm{mg})$ was further added Then, the oxidation step was performed at $80^{\circ} \mathrm{C}$ for $30 \mathrm{~min}$. Subsequently, $\mathrm{HAuCl}_{4} \cdot 3 \mathrm{H}_{2} \mathrm{O}(2 \mathrm{~mol} \%)$, amine $4 \mathrm{a}$, c $(0.55 \mathrm{mmol})$ and alkyne $3 \mathrm{a}(0.6 \mathrm{mmol})$ were added to the same vessel at $80^{\circ} \mathrm{C}$ for the necessary reaction time. (b) $\mathrm{HAuCl}_{4} \cdot 3 \mathrm{H}_{2} \mathrm{O}(2 \mathrm{~mol} \%)$ was solved in $0.5 \mathrm{~mL}$ of toluene and then, aldehyde $\mathbf{2 d}-\mathbf{g}, \mathbf{i}(0.5 \mathrm{mmol})$, amine $4 \mathbf{a}, \mathbf{c}$ $(0.55 \mathrm{mmol})$ and alkyne $3 \mathrm{a}(0.6 \mathrm{mmol})$ were added at $80{ }^{\circ} \mathrm{C}$ for the necessary reaction time. ${ }^{(\mathrm{c})}$ Conversion by ${ }^{1} \mathrm{H}-\mathrm{NMR}$ with respect to the aldehyde.

It is remarkable that starting from the alcohols $\mathbf{1 d}-\mathbf{g}, \mathbf{i}$, the reaction gives rise to better conversions in all cases after the same reaction time, in comparison with aldehydes $\mathbf{2} \mathbf{d}-\mathbf{g}$,i. Hence, quantitative conversions are obtained with alcohols, while the reactions with the aldehydes are slower. As commented in the Introduction Section, it is well-known that aldehydes have traces of acid, generated in the bottle of the reagents over time. However, we believe that these traces are not generated during the oxidation step, since between the in situ generation of the aldehyde and the successive catalytic gold process, where the aldehyde is consumed, only a short time goes by (3-18 h). Therefore, when aldehydes are used, these traces can influence the reactivity of the process and, consequently, the yield of the reaction, supporting the differences found, as we previously observed for other different processes [13,14]. 
Additionally, in order to know if the $\mathrm{MnO}_{2}$ can participate somehow in the successive catalytic step, beyond the oxidation step, we have first performed a background reaction starting from aldehyde $\mathbf{2} \mathbf{a}$ and in the absence of gold (Scheme 2a). However, the propargylamine is not formed. Therefore, the $\mathrm{MnO}_{2}$ does not catalyze the process by itself alone and the gold catalyst is necessary. An additional proof has been carried out, also adding 3 equiv. of $\mathrm{MnO}_{2}$ in the catalytic gold reaction starting from aldehyde $\mathbf{2 e}$ and $\mathbf{2 f}$ (Scheme $2 \mathbf{b}$ ) in order to know if the presence of $\mathrm{MnO}_{2}$ in the medium can increase the yield of the reaction. In these cases, almost the same conversions were found $(87 \%$ and $87 \%$ ) as those reported in entries 4 and 6 (Table 3), respectively. Therefore, we can discard, as far as we know, the role and participation of the $\mathrm{MnO}_{2}$ in the successive steps of the catalytic mechanism, neither catalyzing the formation of the propargylamine by itself nor helping in some of the steps of the catalytic cycle. These findings support the use of alcohols in many processes instead of the corresponding aldehydes, as a more convenient, stable and easier to handle reagent, and the importance of our developed methodology.

a) Background of the process
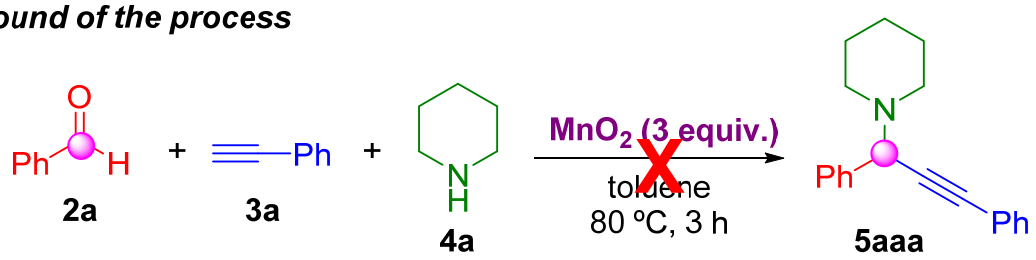

b) Role of $\mathrm{MnO}_{2}$ in the catalytic cycle

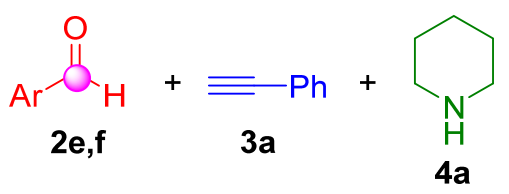

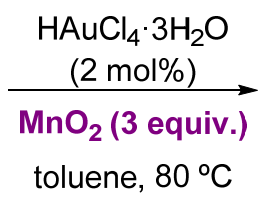

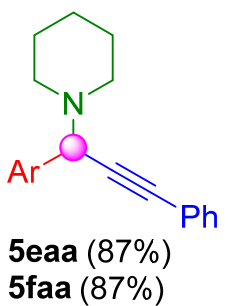

Scheme 2. Role of $\mathrm{MnO}_{2}$ in the synthesis of propargylamines starting from aldehydes.

Furthermore, on the bases of the experimental results and in previous works [54,55], a plausible reaction mechanism is depicted in Scheme 3.

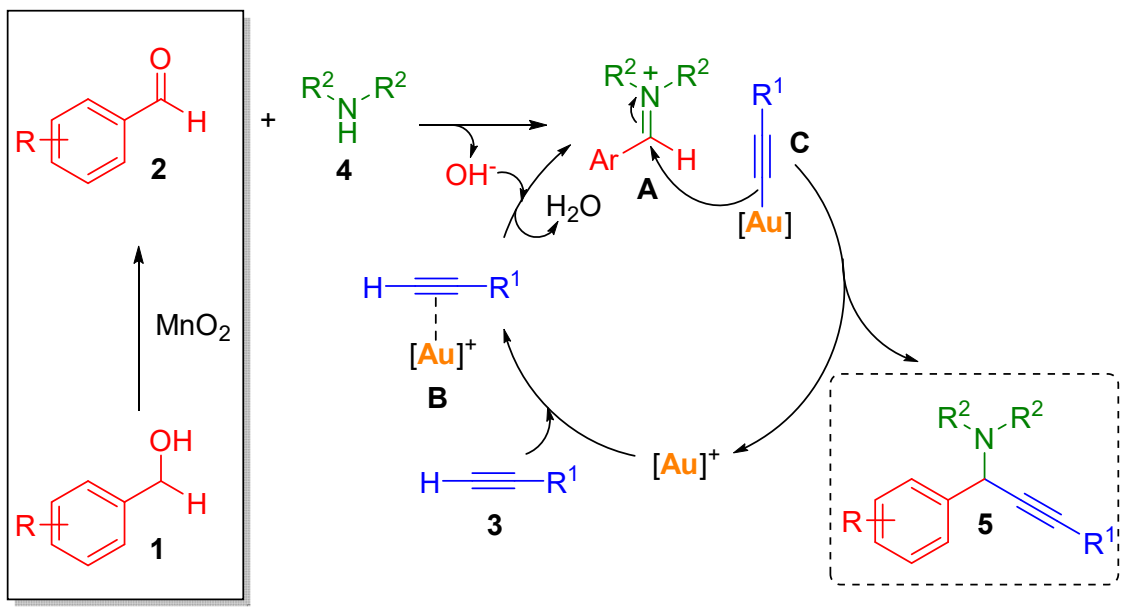

Scheme 3. Plausible reaction pathways.

After an in situ oxidation of the alcohol, the generated aldehyde 2 initially reacts with the secondary amine, giving rise to the iminium ion A. A concomitant step is the formation of a $\pi$-metal-alkyne intermediate $\mathbf{B}$, involving a $\mathrm{C}-\mathrm{H}$ activation of the alkyne by the gold catalyst. Complex $\mathbf{B}$ should make the alkyne proton more acidic for further 
abstraction. The in situ-generated metal acetylide $\mathbf{C}$ reacts with the iminium ion $\mathbf{A}$, leading to the formation of the propargylamines 5 , releasing the gold catalyst for the subsequent catalytic cycle (Scheme 3).

\section{Materials and Methods}

Purification of reaction products was carried out by column chromatography using silica-gel $(0.063-0.200 \mathrm{~mm})$. Analytical thin-layer chromatography was performed on $0.25 \mathrm{~mm}$ silica gel 60-F plates. ESI (electrospray ionization) and MicroTof-Q mass analyzer (Zaragoza, Spain) were used for HRMS (high resolution mass spectrometry) measurements. ${ }^{1} \mathrm{H}$ NMR spectra were recorded at room temperature on a BRUKER AVANCE 400 spectrometer (Zaragoza, Spain) $\left({ }^{1} \mathrm{H}, 400 \mathrm{MHz}\right)$ or on a BRUKER AVANCE II 300 spectrometer (Zaragoza, Spain) $\left({ }^{1} \mathrm{H}, 300 \mathrm{MHz}\right)$, with chemical shifts (ppm) reported relative to the solvent peaks of the deuterated solvent. $\mathrm{CDCl}_{3}, \mathrm{CD}_{3} \mathrm{CN}$ and $\mathrm{CD}_{3} \mathrm{COCD}_{3}$ were used as the deuterated solvents. Chemical shifts were reported in the $\delta$ scale relative to residual $\mathrm{CHCl}_{3}$ (7.28 ppm), $\mathrm{CH}_{3} \mathrm{CN}$ (1.94 ppm) and $\mathrm{CH}_{3} \mathrm{COCH}_{3}(2.05 \mathrm{ppm})$ for ${ }^{1} \mathrm{H}-\mathrm{NMR}$ and to the central line of $\mathrm{CDCl}_{3}$ (77.16 ppm), $\mathrm{CD}_{3} \mathrm{CN}$ (1.32 ppm) and $\mathrm{CD}_{3} \mathrm{COCD}_{3}(29.84 \mathrm{ppm})$ for ${ }^{13} \mathrm{C}$-APT NMR.

All reactions were performed under air atmosphere and solvents and reagents were used as received without further purification or drying. All reagents were commercially available.

The spectroscopic data recorded for the products obtained: 5aaa [72], 5baa [73], 5caa [74], 5daa [75], 5eaa [74], 5faa [74], 5gaa [73], 5haa [75], 5aab [76], 5aac [75], 5iac [77], 5aad [78], 5aae [79], 5aba [77] and 5aca [77], are in agreement with values previously reported by other authors. However, we report in the Supplementary Material the ${ }^{1} \mathrm{H}$ NMR and ${ }^{13} \mathrm{C}$-APT NMR spectra for each final compound as a proof of their obtainment.

\subsection{General Procedure for the Au-Catalyzed One-Pot/Multicomponent $A^{3}$ Synthesis of Propargylamines 5}

Alcohol 1a-i $(0.5 \mathrm{mmol})$ was solved in $0.5 \mathrm{~mL}$ of toluene and $\mathrm{MnO}_{2}(1.5 \mathrm{mmol}$, $144.9 \mathrm{mg}$ ) was further added. Then, the oxidation step was performed at $80^{\circ} \mathrm{C}$ for $30 \mathrm{~min}$. Subsequently, $\mathrm{HAuCl}_{4} \cdot 3 \mathrm{H}_{2} \mathrm{O}(2 \mathrm{~mol} \%)$, amine $4 \mathbf{a}-\mathbf{e}(0.55 \mathrm{mmol})$ and alkyne $3 \mathbf{a}-\mathbf{c}(0.6 \mathrm{mmol})$ were added to the same vessel at $80^{\circ} \mathrm{C}$ for the necessary reaction time (Table 2). When the reaction is over, the remaining $\mathrm{MnO}_{2}$ is filtered, washing the crude with AcOEt, the solvent was evaporated under vacuum, and the extract was purified by column chromatography (neutral alumina, $n$-hexane:diethylether 95:5), giving rise to the corresponding final adducts 5 with very good results.

\subsection{Characterization of Propargylamines 5}

1-(1,3-Diphenylprop-2-ynyl)piperidine (5aaa) [72]: Following the general procedure described in Table 2, compound 5aaa was isolated by column chromatography after $3 \mathrm{~h}$ of reaction at $80^{\circ} \mathrm{C}$ as a yellow solid in $97 \%$ yield. HRMS (ESI+) calcd for $\mathrm{C}_{20} \mathrm{H}_{21} \mathrm{~N} 276.1747$; found $276.1739[\mathrm{M}+\mathrm{H}]$.

1-(3-Phenyl-1-p-tolylprop-2-ynyl)piperidine (5baa) [73]: Following the general procedure described in Table 2, compound 5baa was isolated by column chromatography after $6 \mathrm{~h}$ of reaction at $80^{\circ} \mathrm{C}$ as a yellow solid in $87 \%$ yield. HRMS (ESI+) calcd for $\mathrm{C}_{21} \mathrm{H}_{24} \mathrm{~N}$ 290.1903; found $290.1910[\mathrm{M}+\mathrm{H}]$.

1-(1-(Naphthalen-1-yl)-3-phenylprop-2-ynyl)piperidine (5caa) [74]: Following the general procedure described in Table 2 but using $3 \mathrm{~mol} \%$ of $\mathrm{HAuCl}_{4} \cdot 3 \mathrm{H}_{2} \mathrm{O}$, compound 5caa was isolated by column chromatography after $4 \mathrm{~h}$ of reaction at $80^{\circ} \mathrm{C}$ as a yellow solid in 90\% yield. HRMS (ESI+) calcd for $\mathrm{C}_{24} \mathrm{H}_{24} \mathrm{~N} 326.1903$; found 326.1891 [M + H] .

1-(1-(3-Nitrophenyl)-3-phenylprop-2-ynyl)piperidine (5daa) [75]: Following the general procedure described in Table 2, compound 5daa was isolated by column chromatography after $3 \mathrm{~h}$ of reaction at $80^{\circ} \mathrm{C}$ as a yellow solid in $90 \%$ yield. HRMS (ESI+) calcd for $\mathrm{C}_{20} \mathrm{H}_{21} \mathrm{~N}_{2} \mathrm{O}_{2}$ 321.1598; found $321.1586[\mathrm{M}+\mathrm{H}]$. 
1-(1-(4-Bromophenyl)-3-phenylprop-2-ynyl)piperidine (5eaa) [74]: Following the general procedure described in Table 2, compound 5eaa was isolated by column chromatography after $6 \mathrm{~h}$ of reaction at $80^{\circ} \mathrm{C}$ as a yellow solid in $94 \%$ yield. HRMS (ESI+) calcd for $\mathrm{C}_{20} \mathrm{H}_{21} \mathrm{BrN}$ 354.0852; found $354.0851[\mathrm{M}+\mathrm{H}]$.

1-(1-(4-Chlorophenyl)-3-phenylprop-2-ynyl)piperidine (5faa) [74]: Following the general procedure described in Table 2, compound 5 faa was isolated by column chromatography after $3 \mathrm{~h}$ of reaction at $80^{\circ} \mathrm{C}$ as a yellow solid in 93\% yield. HRMS (ESI+) calcd for $\mathrm{C}_{20} \mathrm{H}_{21} \mathrm{ClN}$ 310.1357; found 310.1346 [M + H].

1-(1-(3-Chlorophenyl)-3-phenylprop-2-ynyl)piperidine (5gaa) [73]: Following the general procedure described in Table 2, compound 5gaa was isolated by column chromatography after $3 \mathrm{~h}$ of reaction at $80^{\circ} \mathrm{C}$ as a yellow solid in $98 \%$ yield. HRMS (ESI+) calcd for $\mathrm{C}_{20} \mathrm{H}_{21} \mathrm{ClN}$ 310.1357; found 310.1357 [M + H].

1-(1-(4-Fluorophenyl)-3-phenylprop-2-ynyl)piperidine (5haa) [75]: Following the general procedure described in Table 2, compound 5haa was isolated by column chromatography after $3 \mathrm{~h}$ of reaction at $80^{\circ} \mathrm{C}$ as a yellow solid in $94 \%$ yield. HRMS (ESI+) calcd for $\mathrm{C}_{20} \mathrm{H}_{21} \mathrm{FN}$ 294.1653; found $294.1641[\mathrm{M}+\mathrm{H}]$.

1-(1,3-Diphenylprop-2-ynyl)pyrrolidine (5aab) [76]: Following the general procedure described in Table 2, compound 5aab was isolated by column chromatography after $4 \mathrm{~h}$ of reaction at $80^{\circ} \mathrm{C}$ as a yellow solid in $98 \%$ yield. HRMS (ESI+) calcd for $\mathrm{C}_{19} \mathrm{H}_{20} \mathrm{~N} 262.1590$; found $262.1594[\mathrm{M}+\mathrm{H}]$.

4-(1,3-Diphenylprop-2-ynyl)morpholine (5aac) [75]: Following the general procedure described in Table 2, compound 5aac was isolated by column chromatography after $3 \mathrm{~h}$ of reaction at $80{ }^{\circ} \mathrm{C}$ as a yellow solid in $96 \%$ yield. HRMS (ESI+) calcd for $\mathrm{C}_{19} \mathrm{H}_{20} \mathrm{NO} 278.1539$; found $278.1528[\mathrm{M}+\mathrm{H}]$.

4-(1,3-diphenylprop-2-yn-1-yl)morpholine (5iac) [77]: Following the general procedure described in Table 2, compound 5iac was isolated by column chromatography after $6 \mathrm{~h}$ of reaction at $80^{\circ} \mathrm{C}$ as a yellow solid in $85 \%$ yield. HRMS (ESI+) calcd for $\mathrm{C}_{20} \mathrm{H}_{19} \mathrm{~N}_{2} \mathrm{O}$ 303.1492; found $303.1489[\mathrm{M}+\mathrm{H}]$.

$\mathrm{N}$-Butyl-N-(1,3-diphenylprop-2-ynyl)butan-1-amine (5aad) [78]: Following the general procedure described in Table 2, compound 5aad was isolated by column chromatography after $18 \mathrm{~h}$ of reaction at $80{ }^{\circ} \mathrm{C}$ as a yellow solid in 95\% yield. HRMS (ESI+) calcd for $\mathrm{C}_{23} \mathrm{H}_{30} \mathrm{~N}$ 320.2373; found $320.2362[\mathrm{M}+\mathrm{H}]$.

$\mathrm{N}, \mathrm{N}$-diethyl-1,3-diphenylprop-2-yn-1-amine (5aae) [79]: Following the general procedure described in Table 2, compound 5aae was isolated by column chromatography after $18 \mathrm{~h}$ of reaction at $80{ }^{\circ} \mathrm{C}$ as a yellow solid in $96 \%$ yield. HRMS (ESI+) calcd for $\mathrm{C}_{19} \mathrm{H}_{22} \mathrm{~N}$ 264.1747; found $264.1737[\mathrm{M}+\mathrm{H}]$.

1-(1-Phenyl-3-p-tolylprop-2-ynyl)piperidine (5aba) [77]: Following the general procedure described in Table 2, compound 5aba was isolated by column chromatography after $5 \mathrm{~h}$ of reaction at $80{ }^{\circ} \mathrm{C}$ as a yellow solid in $98 \%$ yield. HRMS (ESI+) calcd for $\mathrm{C}_{21} \mathrm{H}_{24} \mathrm{~N}$ 290.1903; found 290.1894 [M + H].

1-(1-phenyl-3-(trimethylsilyl)prop-2-ynyl)piperidine (5aca) [77]: Following the general procedure described in Table 2, compound 5aca was isolated by column chromatography after $18 \mathrm{~h}$ of reaction at $80^{\circ} \mathrm{C}$ as a yellow solid in 98\% yield. HRMS (ESI+) calcd for $\mathrm{C}_{17} \mathrm{H}_{26} \mathrm{NSi}$ 272.1829; found 272.1821 [M + H].

\subsection{Crystal Structure Determinations}

Crystals were mounted in inert oil on glass fibers and transferred to the cold gas stream of a Bruker Apex Duo diffractometer (Zaragoza, Spain), equipped with a lowtemperature attachment. Data were collected using monochromated MoK $\alpha$ radiation $(\lambda=0.71073 \AA$ ). Scan type $\omega$. Absorption correction based on multiple scans was applied using SADABS. The structures were solved by direct methods and refined on $F^{2}$ using the program SHELXL-2016 [80]. All non-hydrogen atoms were refined anisotropically. CCDC (Cambridge Crystallographic Data Centre) deposition numbers 2067799 (5aaa) and 2067800 
(5caa) contain the supplementary crystallographic data. These data can be obtained free of charge by The Cambridge Crystallography Data Center.

\section{Conclusions}

The results reported in this manuscript represent a straightforward and sustainable synthesis of propargylamines, compounds of extraordinary importance in pharmaceutical chemistry, starting from readily available alcohols. The procedure progresses with excellent yields in a short time and using commercially available oxidant and catalyst. We showed that it is not only possible to avoid starting directly from aldehydes for the preparation of propargylamines, but also the atomic economy and yield efficiency properties are preserved maintaining the original characteristics of a one-pot protocol followed by a MCR process. This one-pot/multicomponent reaction starting from alcohols to generate aldehydes and a subsequent cascade reaction with amines and alkynes to reach the desired final products under gold catalysis could be considered as a formal $\mathrm{A}^{3}$-coupling reaction. Our developed procedure represents a pivotal example of this undeveloped approach.

Supplementary Materials: The following are available online at https:/ /www.mdpi.com/article/10.3 390/catal11040513/s1, Figure S1: ${ }^{1} \mathrm{H}$ and ${ }^{13} \mathrm{C}-\mathrm{APT}\left(\mathrm{CD}_{3} \mathrm{COCD}_{3}\right)$ NMR spectra of 1-(1,3-diphenylprop-2ynyl)piperidine (5aaa), Figure $\mathrm{S} 2:{ }^{1} \mathrm{H}\left(\mathrm{CDCl}_{3}\right)$ and ${ }^{13} \mathrm{C}-\mathrm{APT}\left(\mathrm{CD}_{3} \mathrm{CN}\right) \mathrm{NMR}$ spectra of 1-(3-phenyl1-p-tolylprop-2-ynyl)piperidine (5baa), Figure $33:{ }^{1} \mathrm{H}\left(\mathrm{CD}_{3} \mathrm{COCD}_{3}\right)$ and ${ }^{13} \mathrm{C}-\mathrm{APT}\left(\mathrm{CD}_{3} \mathrm{CN}\right) \mathrm{NMR}$ spectra of 1-(1-(naphthalen-1-yl)-3-phenylprop-2-ynyl)piperidine (5caa), Figure $\mathrm{S4}:{ }^{1} \mathrm{H}$ and ${ }^{13} \mathrm{C}$-APT $\left(\mathrm{CD}_{3} \mathrm{CN}\right)$ NMR spectra of 1-(1-(3-nitrophenyl)-3-phenylprop-2-ynyl)piperidine (5daa), Figure $55:{ }^{1} \mathrm{H}$ and ${ }^{13} \mathrm{C}-\mathrm{APT}\left(\mathrm{CD}_{3} \mathrm{CN}\right)$ NMR spectra of 1-(1-(4-bromophenyl)-3-phenylprop-2-ynyl)piperidine (5eaa), Figure S6: ${ }^{1} \mathrm{H}$ and ${ }^{13} \mathrm{C}$-APT $\left(\mathrm{CD}_{3} \mathrm{COCD}_{3}\right)$ NMR spectra of 1-(1-(4-chlorophenyl)-3-phenylprop-2ynyl)piperidine (5faa), Figure $57:{ }^{1} \mathrm{H}$ and ${ }^{13} \mathrm{C}-\mathrm{APT}\left(\mathrm{CD}_{3} \mathrm{CN}\right)$ NMR spectra of 1-(1-(3-chlorophenyl)3-phenylprop-2-ynyl)piperidine (5gaa), Figure $\mathrm{S} 8:{ }^{1} \mathrm{H}$ and ${ }^{13} \mathrm{C}-\mathrm{APT}\left(\mathrm{CD}_{3} \mathrm{CN}\right) \mathrm{NMR}$ spectra of 1(1-(4-fluorophenyl)-3-phenylprop-2-ynyl)piperidine (5haa), Figure S9: ${ }^{1} \mathrm{H}\left(\mathrm{CDCl}_{3}\right)$ and ${ }^{13} \mathrm{C}$-APT $\left(\mathrm{CD}_{3} \mathrm{CN}\right)$ NMR spectra of 1-(1,3-diphenylprop-2-ynyl)pyrrolidine (5aab), Figure $\mathrm{S} 10:{ }^{1} \mathrm{H}$ and ${ }^{13} \mathrm{C}$ $\mathrm{APT}\left(\mathrm{CD}_{3} \mathrm{CN}\right) \mathrm{NMR}$ spectra of 4-(1,3-diphenylprop-2-ynyl)morpholine (5aac), Figure $\mathrm{S11}:{ }^{1} \mathrm{H}$ and ${ }^{13} \mathrm{C}-\mathrm{APT}\left(\mathrm{CD}_{3} \mathrm{CN}\right)$ NMR spectra of 4-(1-morpholino-3-phenylprop-2-yn-1-yl)benzonitrile (5iac), Figure S12: ${ }^{1} \mathrm{H}\left(\mathrm{CDCl}_{3}\right)$ and ${ }^{13} \mathrm{C}$-APT $\left(\mathrm{CD}_{3} \mathrm{CN}\right)$ NMR spectra of $\mathrm{N}$-butyl- $\mathrm{N}$-(1,3-diphenylprop-2ynyl)butan-1-amine (5aad), Figure S13: ${ }^{1} \mathrm{H}$ and ${ }^{13} \mathrm{C}$-APT $\left(\mathrm{CD}_{3} \mathrm{CN}\right)$ NMR spectra of $N, N$-diethyl1,3-diphenylprop-2-yn-1-amine (5aae), Figure S14: ${ }^{1} \mathrm{H}$ and ${ }^{13} \mathrm{C}-\mathrm{APT}\left(\mathrm{CD}_{3} \mathrm{CN}\right) \mathrm{NMR}$ spectra of 1-(1-phenyl-3-p-tolylprop-2-ynyl)piperidine (5aba), Figure S15: ${ }^{1} \mathrm{H}\left(\mathrm{CDCl}_{3}\right)$ and ${ }^{13} \mathrm{C}-\mathrm{APT}\left(\mathrm{CD}_{3} \mathrm{CN}\right)$ NMR spectra of 1-(1-phenyl-3-(trimethylsilyl)prop-2-ynyl)piperidine (5aca).

Author Contributions: Conceptualization, M.C.G. and R.P.H.; Methodology, Software, Validation, Formal Analysis, Investigation, Resources, Data Curation, all authors; Writing-Original Draft Preparation, M.C.G. and R.P.H.; Writing—Review and Editing, all authors; Visualization, M.C.G. and R.P.H.; Supervision M.C.G. and R.P.H.; Project Administration, M.C.G. and R.P.H.; Funding Acquisition, M.C.G. and R.P.H. All authors have read and agreed to the published version of the manuscript.

Funding: This research was funded by Agencia Estatal de Investigación (AEI), projects CTQ201788091-P and PID2019-104379RB-C21, and Gobierno de Aragón-Fondo Social Europeo (Research Group E07_20R).

Acknowledgments: S.Z.-R. thanks Consejo Nacional de Ciencia y Tecnología (CONACYT, Mexico) for a predoctoral fellowship.

Conflicts of Interest: The authors declare no conflict of interest.

\section{References}

1. Walji, A.M.; MacMillan, W.C. Strategies to Bypass the Taxol Problem. Enantioselective Cascade Catalysis, a New Approach for the Efficient Construction of Molecular Complexity. Synlett 2007, 1477-1489. [CrossRef]

2. Zhao, W.; Chen, F.-E. One-pot Synthesis and its Practical Application in Pharmaceutical Industry. Curr. Org. Chem. 2012, 9, 873-897. [CrossRef]

3. Hayashi, Y. Pot economy and one-pot synthesis. Chem. Sci. 2016, 7, 866-880. [CrossRef] [PubMed]

4. Corma, A.; Navas, J.; Sabater, M.J. Advances in One-Pot Synthesis through Borrowing Hydrogen Catalysis. Chem. Rev. 2018, 118, 1410-1459. [CrossRef] 
5. Zhu, J.; Bienaymé, H. (Eds.) Multicomponent Reactions; Wiley-VCH: Weinheim, Germany, 2005.

6. Zhu, J.; Wang, Q.; Wang, M.-X. (Eds.) Multicomponent Reactions in Organic Synthesis; Wiley-VCH: Weinheim, Germany, 2014.

7. Herrera, R.P.; Marqués-López, E. (Eds.) Multicomponent Reactions: Concepts and Applications for Design and Synthesis; John Wiley \& Sons: Hoboken, NJ, USA, 2015.

8. Weber, L. The application of multi-component reactions in drug discovery. Curr. Med. Chem. 2002, 9, 2085-2093. [CrossRef] [PubMed]

9. Hulme, C.; Gore, V. Multi-component reactions: Emerging chemistry in drug discovery from xylocain to crixivan. Curr. Med. Chem. 2003, 10, 51-80. [CrossRef]

10. Touré, B.B.; Hal, D.G. Natural Product Synthesis Using Multicomponent Reaction Strategies. Chem. Rev. 2009, 109, 4439-4486. [CrossRef]

11. Dömling, A.; Wang, W.; Wang, K. Chemistry and Biology of Multicomponent Reactions. Chem. Rev. 2012, 112, 3083-3135. [CrossRef]

12. Tojo, G.; Fernandez, M.I. (Eds.) Oxidation of Alcohols to Aldehydes and Ketones: A Guide to Current Common Practice; Springer: New York, NY, USA, 2006.

13. Alegre-Requena, J.V.; Marqués-López, E.; Herrera, R.P. Trifunctional Squaramide Catalyst for Efficient Enantioselective Henry Reaction Activation. Adv. Synth. Catal. 2016, 358, 1801-1809. [CrossRef]

14. Alegre-Requena, J.V.; Marqués-López, E.; Herrera, R.P. Organocatalyzed Enantioselective Aldol and Henry Reactions Starting from Benzylic Alcohols. Adv. Synth. Catal. 2018, 360, 124-129. [CrossRef]

15. Quintard, A.; Alexakis, A.; Mazet, C. Access to high levels of molecular complexity by one-pot iridium/enamine asymmetric catalysis. Angew. Chem. Int. Ed. 2011, 50, 2354-2358. [CrossRef] [PubMed]

16. Rueping, M.; Sundén, H.; Sugiono, E. Unifying Metal- and Organocatalysis for Asymmetric Oxidative Iminium Activation: A Relay Catalytic System Enabling the Combined Allylic Oxidation of Alcohols and Prolinol Ether Catalyzed Iminium Reactions. Chem. Eur. J. 2012, 18, 3649-3653. [CrossRef] [PubMed]

17. Rueping, M.; Sundén, H.; Hubener, L.; Sugiono, E. Asymmetric oxidative Lewis base catalysis-unifying iminium and enamine organocatalysis with oxidations. Chem. Commun. 2012, 48, 2201-2203. [CrossRef] [PubMed]

18. Suh, C.W.; Kim, D.Y. Enantioselective One-Pot Synthesis of Ring-Fused Tetrahydroquinolines via Aerobic Oxidation and 1,5-Hydride Transfer/Cyclization Sequences. Org. Lett. 2014, 16, 5374-5377. [CrossRef] [PubMed]

19. Rana, N.K.; Joshi, H.; Jha, R.K.; Singh, V.K. Enantioselective Tandem Oxidation/Michael-Aldol Approaches to Tetrasubstituted Cyclohexanes. Chem. Eur. J. 2017, 23, 2040-2043. [CrossRef]

20. Wei, C.; Li, Z.; Li, C.-J. The Development of $\mathrm{A}^{3}$ Coupling (Aldehyde-Alkyne-Amine) and AA ${ }^{3}$ Coupling (Asymmetric AldehydeAlkyne-Amine). Synlett 2004, 1472-1483. [CrossRef]

21. Yoo, W.-Y.; Zhao, L.; Li, C.-J. The A ${ }^{3}$-Coupling (Aldehyde-Alkyne-Amine) Reaction: A Versatile Method for the Preparation of Propargylamines. Aldrichim. Acta 2011, 44, 43-51.

22. Peshkov, V.A.; Pereshivko, O.P.; Van der Eycken, E.V. A walk around the $\mathrm{A}^{3}$-coupling. Chem. Soc. Rev. 2012, 41, 3790-3807. [CrossRef]

23. Lauder, K.; Toscani, A.; Scalacci, N.; Castagnolo, D. Synthesis and Reactivity of Propargylamines in Organic Chemistry. Chem. Rev. 2017, 117, 14091-14200. [CrossRef]

24. Saha, T.K.; Das, R. Progress in Synthesis of Propargylamine and Its Derivatives by Nanoparticle Catalysis via $\mathrm{A}^{3}$ coupling: A Decade Update. ChemistrySelect 2018, 3, 147-169. [CrossRef]

25. Rokade, B.V.; Barker, J.; Guiry, P.J. Development of and recent advances in asymmetric $\mathrm{A}^{3}$ coupling. Chem. Soc. Rev. 2019, 48, 4766-4790. [CrossRef]

26. Jesin, I.; Nandi, G.C. Recent Advances in the $\mathrm{A}^{3}$ Coupling Reactions and their Applications. Eur. J. Org. Chem. 2019, 2704-2720. [CrossRef]

27. Edmondson, D.E.; Mattevi, A.; Binda, C.; Li, M.; Hubálek, F. Structure and mechanism of monoamine oxidase. Curr. Med. Chem. 2004, 11, 1983-1993. [CrossRef] [PubMed]

28. Orhan, I.E. Potential of Natural Products of Herbal Origin as Monoamine Oxidase Inhibitors. Curr. Pharm. Des. 2016, 22, 268-276. [CrossRef]

29. King, R.W.; Klabe, R.M.; Reid, C.D.; Erickson-Viitanen, S.K. Potency of Nonnucleoside Reverse Transcriptase Inhibitors (NNRTIs) Used in Combination with Other Human Immunodeficiency Virus NNRTIs, NRTIs, or Protease Inhibitors. Antimicrob. Agents Chemother. 2002, 46, 1640-1646. [CrossRef]

30. Li, S.; Ma, J.-A. Core-structure-inspired asymmetric addition reactions: Enantioselective synthesis of dihydrobenzoxazinone- and dihydroquinazolinone-based anti-HIV agents. Chem. Soc. Rev. 2015, 44, 7439-7448. [CrossRef]

31. Nugent, W.A. Exploring Chiral Space en route to DPC 963: A Personal Account. Adv. Synth. Catal. 2003, 345, 415-424. [CrossRef]

32. Hashmi, A.S.K.; Hutchings, G.J. Gold Catalysis. Angew. Chem. Int. Ed. 2006, 45, 7896-7936. [CrossRef] [PubMed]

33. Hashmi, A.S.K. Gold-Catalyzed Organic Reactions. Chem. Rev. 2007, 107, 3180-3211. [CrossRef] [PubMed]

34. Fürstner, A.; Davies, P.W. Catalytic Carbophilic Activation: Catalysis by Platinum and Gold $\pi$ Acids. Angew. Chem. Int. Ed. 2007, 119, 3478-3519. [CrossRef]

35. Li, Z.; Brouwer, C.; He, C. Gold-Catalyzed Organic Transformations. Chem. Rev. 2008, 108, 3239-3265. [CrossRef] 
36. Arcadi, A. Alternative Synthetic Methods through New Developments in Catalysis by Gold. Chem. Rev. 2008, $108,3266-3325$. [CrossRef] [PubMed]

37. Jiménez-Nuñez, E.; Echavarren, A.M. Gold-Catalyzed Cycloisomerizations of Enynes: A Mechanistic Perspective. Chem. Rev. 2008, 108, 3326-3350. [CrossRef]

38. Gorin, D.J.; Sherry, B.D.; Toste, F.D. Ligand Effects in Homogeneous Au Catalysis. Chem. Rev. 2008, 108, 3351-3378. [CrossRef] [PubMed]

39. Sengupta, S.; Shi, X. Recent Advances in Asymmetric Gold Catalysis. ChemCatChem. 2010, 2, 609-619. [CrossRef]

40. Garayalde, D.; Nevado, C. Synthetic applications of gold-catalyzed ring expansions. Beilstein J. Org. Chem. 2011, 7, 767-780. [CrossRef] [PubMed]

41. Rudolph, M.; Hashmi, A.S.K. Gold catalysis in total synthesis-An update. Chem. Soc. Rev. 2012, 41, 2448-2462. [CrossRef] [PubMed]

42. Visbal, R.; Graus, S.; Herrera, R.P.; Gimeno, M.C. Gold Catalyzed Multicomponent Reactions beyond A ${ }^{3}$ Coupling. Molecules 2018, 23, 2255. [CrossRef]

43. Herrera, R.P.; Gimeno, M.C. Main Avenues in Gold Coordination Chemistry. Chem. Rev. 2021. [CrossRef]

44. Wei, C.; Li, C.-J. A Highly Efficient Three-Component Coupling of Aldehyde, Alkyne, and Amines via C-H Activation Catalyzed by Gold in Water. J. Am. Chem. Soc. 2003, 125, 9584-9585. [CrossRef] [PubMed]

45. Lo, V.K.-Y.; Liu, Y.; Wong, M.-K.; Che, C.-M. Gold(III) Salen Complex-Catalyzed Synthesis of Propargylamines via a ThreeComponent Coupling Reaction. Org. Lett. 2006, 8, 1529-1532. [CrossRef]

46. Elie, B.T.; Levine, C.; Ubarretxena-Belandia, I.; Varela-Ramírez, A.; Aguilera, R.J.; Ovalle, R.; Contel, M. Water Soluble PhosphaneGold(I) Complexes. Applications as Recyclable Catalysts in a Three-component Coupling Reaction and as Antimicrobial and Anticancer Agents. Eur. J. Inorg. Chem. 2009, 3421-3430. [CrossRef]

47. Oña-Burgos, P.; Fernández, I.; Roces, L.; Fernández, L.T.; García-Granada, S.; Ortiz, F.L. An unprecedented phosphinamidic gold(III) metallacycle: Synthesis via tin(IV) precursors, structure, and multicomponent catalysis. Organometallics 2009, 28, 1739-1747. [CrossRef]

48. Ko, H.-M.; Kung, K.K.-Y.; Cui, J.-F.; Wong, M.-K. Bis-cyclometallated gold(III) complexes as efficient catalysts for synthesis of propargylamines and alkylated indoles. Chem. Commun. 2013, 49, 8869-8871. [CrossRef] [PubMed]

49. Abbiati, G.; Rossi, E. Silver and gold-catalyzed multicomponent reactions. Beilstein J. Org. Chem. 2014, 10, 481-513. [CrossRef]

50. Kung, K.K.-Y.; Lo, V.K.-Y.; Ko, H.-M.; Li, G.-L.; Chan, P.-Y.; Leung, K.-C.; Zhou, Z.; Wang, M.-Z.; Che, C.-M.; Wong, M.-K. Cyclometallated Gold(III) Complexes as Effective Catalysts for Synthesis of Propargylic Amines, Chiral Allenes and Isoxazoles. Adv. Synth. Catal. 2013, 355, 2055-2070. [CrossRef]

51. von Wachenfeldt, H.; Polukeev, A.V.; Loganathan, N.; Paulsen, F.; Röse, P.; Garreau, M.; Wendt, O.F.; Strand, D. Cyclometallated gold(III) aryl-pyridine complexes as efficient catalysts for three-component synthesis of substituted oxazoles. Dalton Trans. 2015, 44, 5347-5353. [CrossRef]

52. Hui, T.-W.; Cui, J.-F.; Wong, M.-K. Modular synthesis of propargylamine modified cyclodextrins by a gold(III)-catalyzed three-component coupling reaction. RSC Adv. 2017, 7, 14477-14480. [CrossRef]

53. Grirrane, A.; Álvarez, E.; García, H.; Corma, A. Double A ${ }^{3}$-Coupling of Primary Amines Catalysed by Gold Complexes. Chem. Eur. J. 2018, 24, 16356-16367. [CrossRef] [PubMed]

54. Montanel-Pérez, S.; Herrera, R.P.; Laguna, A.; Villacampa, M.D.; Gimeno, M.C. The fluxional amine gold(iii) complex as an excellent catalyst and precursor of biologically active acyclic carbenes. Dalton Trans. 2015, 44, 9052-9062. [CrossRef]

55. Aliaga-Lavrijsen, M.; Herrera, R.P.; Villacampa, M.D.; Gimeno, M.C. Efficient Gold(I) Acyclic Diaminocarbenes for the Synthesis of Propargylamines and Indolizines. ACS Omega 2018, 3, 9805-9813. [CrossRef] [PubMed]

56. Corma, A.; Navas, J.; Sabater, M.J. Coupling of Two Multistep Catalytic Cycles for the One-Pot Synthesis of Propargylamines from Alcohols and Primary Amines on a Nanoparticulated Gold Catalyst. Chem. Eur. J. 2012, 18, 14150-14156. [CrossRef]

57. Lili, L.; Xin, Z.; Jinsen, G.; Chunming, X. Engineering metal-organic frameworks immobilize gold catalysts for highly efficient one-pot synthesis of propargylamines. Green Chem. 2012, 14, 1710-1720. [CrossRef]

58. Karimi, B.; Gholinejad, M.; Khorasani, M. Highly efficient three-component coupling reaction catalyzed by gold nanoparticles supported on periodic mesoporous organosilica with ionic liquid framework. Chem. Commun. 2012, 48, 8961-8963. [CrossRef] [PubMed]

59. Gonzalez-Bejar, M.; Peters, K.; Hallett-Tapley, G.L.; Grenier, M.; Scaiano, J.C. Rapid one-pot propargylamine synthesis by plasmon mediated catalysis with gold nanoparticles on ZnO under ambient conditions. Chem. Commun. 2013, 49, 1732-1734. [CrossRef]

60. Anand, N.; Ramudu, P.; Reddy, K.H.P.; Rao, K.S.R.; Jagadeesh, B.; Babu, V.S.P.; Burri, D.R. Gold nanoparticles immobilized on lipoic acid functionalized SBA-15: Synthesis, characterization and catalytic applications. Appl. Catal. A Gen. 2013, 454, 119-126. [CrossRef]

61. Borah, B.J.; Borah, S.J.; Saikia, K.; Dutta, D.K. Efficient one-pot synthesis of propargylamines catalysed by gold nanocrystals stabilized on montmorillonite. Catal. Sci. Technol. 2014, 4, 4001-4009. [CrossRef]

62. Moghaddam, F.M.; Ayati, S.E.; Hosseini, S.H.; Pourjavadi, A. Gold immobilized onto poly(ionic liquid) functionalized magnetic nanoparticles: A robust magnetically recoverable catalyst for the synthesis of propargylamine in water. RSC Adv. 2015, 5, 34502-34510. [CrossRef] 
63. Feiz, A.; Bazgir, A. Gold nanoparticles supported on mercaptoethanol directly bonded to MCM-41: An efficient catalyst for the synthesis of propargylamines. Catal. Commun. 2016, 73, 88-92. [CrossRef]

64. Loni, M.; Yazdani, H.; Bazgir, A. Gold Nanoparticles-Decorated Dithiocarbamate Nanocomposite: An Efficient Heterogeneous Catalyst for the Green A3-Coupling Synthesis of Propargylamines. Catal. Lett. 2018, 148, 3467-3476. [CrossRef]

65. Soengas, R.; Navarro, Y.; Iglesias, M.J.; López-Ortiz, F. Immobilized Gold Nanoparticles Prepared from Gold(III)-Containing Ionic Liquids on Silica: Application to the Sustainable Synthesis of Propargylamines. Molecules 2018, 23, 2975. [CrossRef] [PubMed]

66. Aghahosseini, H.; Rezaei, S.J.T.R.; Tadayyon, M.; Ramazani, A.; Amani, V.; Ahmadi, R.; Abdolahnjadian, D. Highly Efficient Aqueous Synthesis of Propargylamines through C-H Activation Catalyzed by Magnetic Organosilica-Supported. Gold Nanoparticles as an Artificial Metalloenzyme. Eur. J. Inorg. Chem. 2018, 2589-2598. [CrossRef]

67. Bensaad, M.; Berrichi, A.; Bachir, R.; Bedrane, S. Nano and Sub-nano Gold-Cobalt Particles as Effective Catalysts in the Synthesis of Propargylamines via AHA Coupling. Catal. Lett. 2021, 151, 1068-1079. [CrossRef]

68. Sagadevan, A.; Pampana, V.K.K.; Hwang, K.C. Copper Photoredox Catalyzed A3' Coupling of Arylamines, Terminal Alkynes, and Alcohols through a Hydrogen Atom Transfer Process. Angew. Chem. Int. Ed. 2019, 58, 3838-3842. [CrossRef]

69. Hosseinzadeh, S.Z.; Babazadeh, M.; Shahverdizadeh, G.H.; Es'haghi, M.; Hossinzadeh-Khanmiri, R. Silica Encapsulated-Gold Nanoparticles as a Nano-reactor for Aerobic Oxidation of Benzyl alcohols and Tandem Oxidative A3 coupling Reactions in Water. Catal. Lett. 2020, 150, 2784-2791. [CrossRef]

70. Movahed, S.K.; Lehi, N.F.; Dabiri, M. Gold nanoparticle supported on ionic liquidmodified graphene oxide as an efficient and recyclable catalyst for one-pot oxidative $\mathrm{A}^{3}$ - coupling reaction of benzyl alcohols. RSC Adv. 2014, 4, 42155-42158. [CrossRef]

71. Fatiadi, A.J. Active Manganese Dioxide Oxidation in Organic Chemistry-Part I. Synthesis 1976, 65-104. [CrossRef]

72. Leadbeater, N.E.; Torenius, H.M.; Tye, H. Microwave-assisted Mannich-type three-component reactions. Mol. Divers. 2003, 7, 135-144. [CrossRef] [PubMed]

73. Mitamura, T.; Ogawa, A. Copper(0)-Induced Deselenative Insertion of N,N-Disubstituted Selenoamides into Acetylenic C-H Bond Leading to Propargylamines. Org. Lett. 2009, 11, 2045-2048. [CrossRef]

74. Chng, L.L.; Yang, J.; Wei, Y.; Ying, J.Y. Semiconductor-Gold Nanocomposite Catalysts for the Efficient Three-Component Coupling of Aldehyde, Amine and Alkyne in Water. Adv. Synth. Catal. 2009, 351, 2887-2896.

75. Layek, K.; Chakravarti, R.; Kantam, M.L.; Maheswaran, H.; Vinu, A. Nanocrystalline magnesium oxide stabilized gold nanoparticles: An advanced nanotechnology based recyclable heterogeneous catalyst platform for the one-pot synthesis of propargylamines. Green Chem. 2011, 13, 2878-2887. [CrossRef]

76. Zhang, X.; Corma, A. Supported gold(III) catalysts for highly efficient three-component coupling reactions. Angew. Chem. Int. Ed. 2008, 47, 4358-4361. [CrossRef] [PubMed]

77. Ramu, E.; Varala, R.; Sreelatha, N.; Adapa, S.R. $\mathrm{Zn}(\mathrm{OAc})_{2} \cdot 2 \mathrm{H}_{2} \mathrm{O}$ : A versatile catalyst for the one-pot synthesis of propargylamines. Tetrahedron Lett. 2007, 48, 7184-7190. [CrossRef]

78. Feng, H.; Ermolat'ev, D.S.; Song, G.; Van der Eycken, E.V. Microwave-Assisted Decarboxylative Three-Component Coupling of a 2-Oxoacetic Acid, an Amine, and an Alkyne. J. Org. Chem. 2011, 76, 7608-7613. [CrossRef] [PubMed]

79. Sakai, N.; Hirasawa, M.; Konakahara, T. $\mathrm{InBr}_{3}-\mathrm{Et}_{3} \mathrm{~N}$ promoted alkynylation of aldehydes and N,O-acetals under mild conditions: Facile and simple preparation of propargylic alcohols and amines. Tetrahedron Lett. 2003, 44, 4171-4174. [CrossRef]

80. Sheldrick, G.M. Crystal structure refinement with SHELXL. Acta Cryst. 2015, C71, 3-8. 